\title{
Design of prototype decision support system for flood detection based on ultrasonic sensor
}

\author{
Yosep Septiana* \\ Sekolah Tinggi Teknologi Garut, Department of Informatics, Jl. Mayor Syamsu No. 1, Garut 44151, Indonesia
}

\begin{abstract}
The system of awareness of the overflow of river water that causes flooding cannot work automatically and in real time in providing a warning about the elevation of river surface that potentially flood. It's caused residents who live around the river area do not know the situation when the river overflow. There are several alternatives to detect river overflow, one of them is by using microcontroller ultrasonic sensor based. The research aims to design prototype decision support system based on the ultrasonic sensor for flood detection that works automatically detects the river overflow. The software development model used is Prototype Model. The result of this research is a prototype in the form of microcontroller ultrasonic sensor based which can be used as flood detection decision support system that will know the height of river surface designed to detect certain level about flood potency with a low-level error.
\end{abstract}

\section{Introduction}

Indonesia is a disaster-prone area [1]. One of them is the usual flooding around the river area. The impacts are not only material losses but also to the point of causing casualties [2]. The impact can be avoid if only the community is more prepared and alerted of the coming of the flood disaster. On the other side, the development of technology has helped human to fix the quality of life [3], one of which is the technology of information [4]. The implementation of technology in information to find solutions to no structured or semi-structured problems could be realized in Decision Support System (DSS) [5]. One of the utilization of DSS can use as an early warning system over natural disaster events, that later, become a device for the dissemination of information about the level of river water level to communities living around the watershed $[6,7,8]$. The researchers identified the absence of a flood detection system that can work automatically and in real time in detecting the water level of the river and disseminating the information to communities around the watershed. Based on the description, the authors formulate the problem to be discussed: how to design prototype of DSS for flood detection based on ultrasonic sensor. For the issues discussed not too widespread, the researchers limit the design first prototype of flood detection system based on ultrasonic sensor which will be the blueprint for further research [9].

DSS is the part of information system for supporting decision for decision making. Refers to several research, an information system has a high capability in decision making, the system has an accurate data accessibility and efficient run-time [10], high accuracy [11], and to support a proper decision [12], low cost [13], extended accessibility [14], intensify user knowledge, increase productivity [15], provide a better data and information [16], and in the certain cases are potentially used as data storage [17].

The purpose of this research is implementing the development of technology in information in the field disaster, especially in detecting the flood by designing DSS for flood detection based on ultrasonic sensor.

\section{Methodology}

The system development method used is the Prototype Model in which the system is built, tested, and then rebuilt. It's until the appropriate result is reached to help develop the whole system [18]. It's a trial-and-error process that works iteratively.

With this method, the final result of the designed DSS will be in accordance with the interpretation, because the design starts from the first prototype until it can actually be implemented $[19,20]$. A prototype is part of the final product that interprets physically or logically before the design and development on a large scale [21].

The stages of designing Prototype Model hardware arrangement is shown in Figure 1.

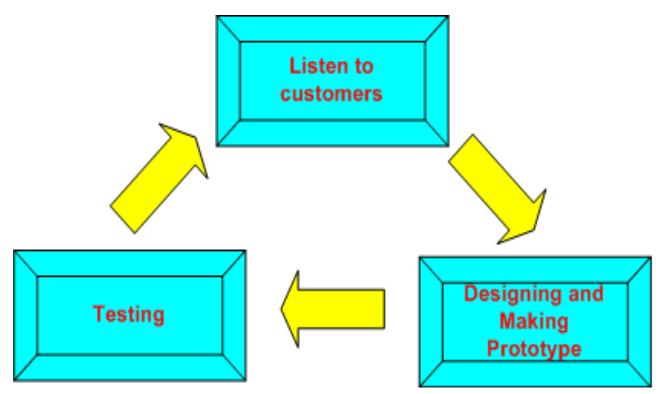

Fig. 1. Stages of Designing Prototype Model.

\footnotetext{
* Corresponding author: yseptiana@sttgarut.ac.id
} 
Stages of designing Prototype Model are as follows: Listen to customers, collecting the needs of the system to be designed based on the problems that occur [22]; Designing and making Prototype, tailored to the needs of the system that has been defined in the previous stage [23]; Trial, do testing to system which has been designed to produce the final product to suit the needs [24].

\section{Result and Discussion}

Decision support system for flood detection to predict flood potential based on river water level that is detected/read by microcontroller based on ultrasonic sensors, placed on several riverbanks. The results of this DSS will be a source of information about the warning of the flood that will be sending in broadband via SMS Gateway to the people who live around the river area.

\subsection{Hardware Design}

The required hardware arrangement is shown in Figure 2.

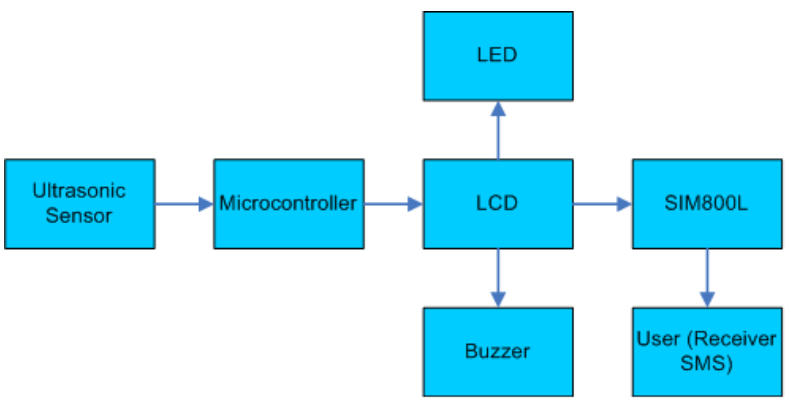

Fig. 2. Hardware Structures.

\subsubsection{Ultrasonic Sensor HC-SR04}

Ultrasonic Sensor HC-SR04, serves to detect the water level of the river, has the accuracy and stability in reading and determining the distance of an object [25].

\subsubsection{Arduino R3 Microcontroller}

Arduino R3 Microcontroller serves to process the input data from the ultrasonic sensor, and its output will be display on the LCD [26], warnings on LED lights, an alarm sounds on the buzzer and GSM SIM 800L module that will send a flood warning message to the communities around the watershed.

\subsubsection{Light Emitting Diode (LED)}

LED lights, serves to warn if the water level rises [27].

\subsubsection{Liquid Crystal Display (LCD)}

LCD serves as a display of a microcontroller [28], to determine the distance of the sensor against the surface of the river water.

\subsubsection{Buzzer}

Buzzer serves as a warning alarm in case of potential flooding.

\subsubsection{GSM SIM800L Module}

GSM SIM800L Module, serves as a tool for disseminating SMS based information [29], to communities around the watershed, in case of potential flooding.

\subsection{Software Design}

Designing software is a stage end from designing tools that are already created; then in Programming, a flowchart should be designed, after that, programs that will be input into the previous tool is designed. Below are stages in designing software, described in Figure 3.

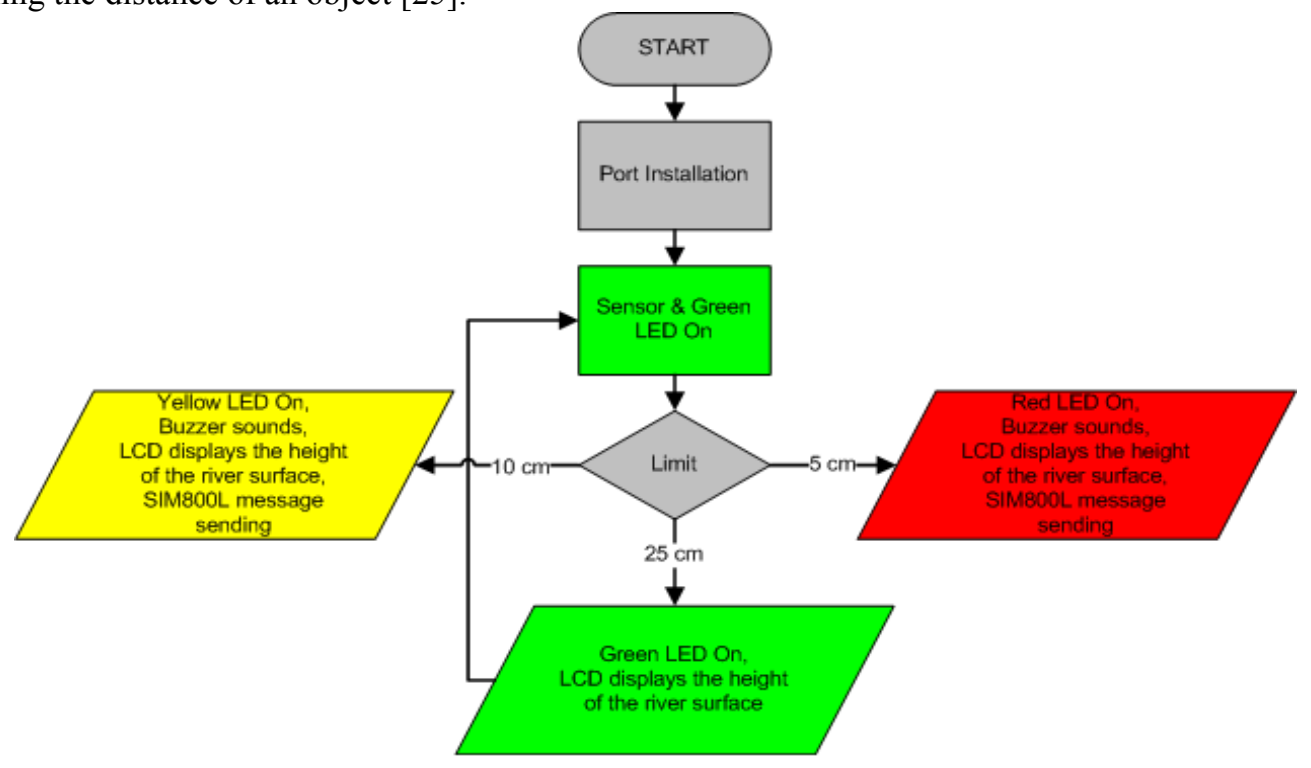

Fig. 3. Software Workflow. 


\subsection{Testing}

Testing of decision support system for flood detection based on ultrasonic sensor is done by testing sensitivity of ultrasonic sensors, the display on LCD, response from LED indicator, SMS notification and alarm/buzzer. Figure 4 illustrates the testing simulation process of prototype DSS for flood detection based on ultrasonic sensor.

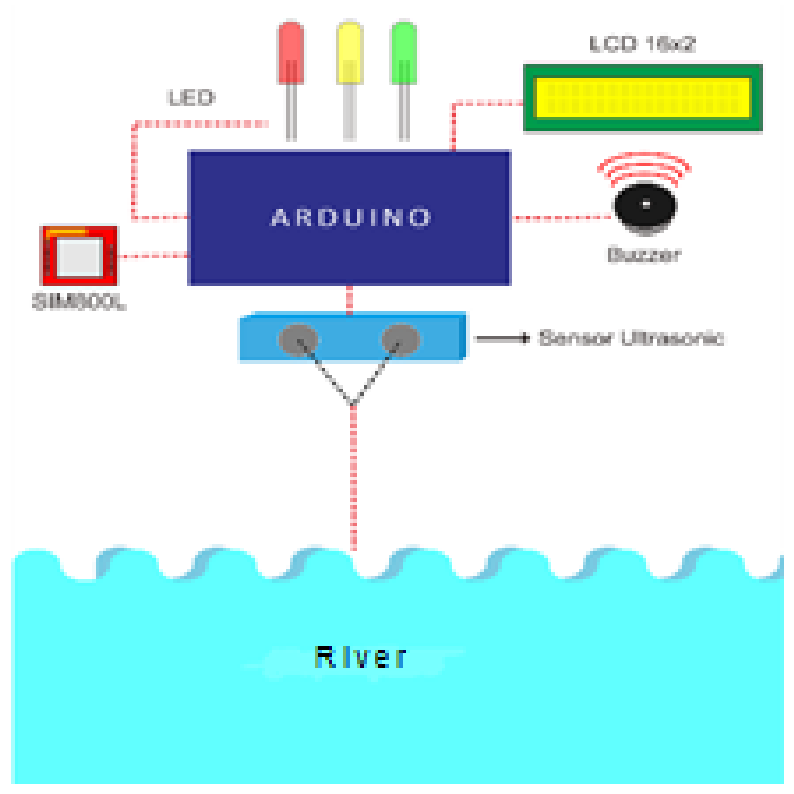

Fig. 4. How the Prototype DSS for Flood Detection works.

Testing on the ultrasonic sensor is performed by checking on sensitivity from sensor to water surface. The result on 5-meter distance, sensor can detect distance of water surface to the sensor and if exceeds distance of 5 meters, then the sensor cannot detect to surface or its level of accuracy is low. Do measurement on the ultrasonic sensor, upon detecting the increase of water level then value output that appears on LCD will change and LED indicator will light up. When the sensor detects simultaneous rise of water level with the LED indicator and results from measurement the water level appears in LCD and will be sending in broadband via SMS Gateway to the people who live around the river area.

For testing purpose, we use the water sensor object that can detect water distance $25 \mathrm{~cm}$; when exceeds $25 \mathrm{~cm}$ then the sensor does not detect water discharge. When the water discharge in position safe within about 20 to $25 \mathrm{~cm}$ from the sensor then green LED will lights up if detected the increase of water discharge reaches $10 \mathrm{~cm}$ distance of the sensor then indicator LED colour yellow to lights up and the alarm will ring and sent SMS to phone users, and if water level already reach position alert which is $5 \mathrm{~cm}$ away from the sensor then indicator LED red will lights up, and the alarm will ring and send in broadband via SMS Gateway to the people who live around the river area.

\section{Conclusion}

Based on the results of research on prototype decision support system for flood detection based on ultrasonic sensor, it can be deduced that the designed decision support system can be used as an alternative to detecting flood, in this case, can measure the river water level automatically, and real time, they can detect if there is potential for flooding. The results of the test show that if the system detects the potential flood, the system will directly alert the form of alarm and notification in the form of SMS Gateway to the people who live around the river area.

\section{References}

1. C. Slamet, A. Rahman, A. Sutedi, W. Darmalaksana, M. A. Ramdhani and D. S. Maylawati, "Social Media-Based Identifier for Natural Disaster," IOP Conference Series: Materials Science and Engineering, vol. 288, no. 1, p. 012039, (2018)

2. I. McCallum and et al, "echnologies to support community flood disaster risk reduction," International Journal of Disaster Risk Science, vol. 7, no. 2, pp. 198-204, (2016)

3. M. A. Ramdhani, H. Aulawi, A. Ikhwana and Y. Mauluddin, "Model of Green Technology Adaptation in Small and Medium-Sized Tannery Industry," Journal of Engineering and Applied Sciences, vol. 12, no. 4, pp. 954-962, (2017)

4. A. Pamoragung, K. Suryadi and M. A. Ramdhani, "Enhancing the Implementation of e-Government in Indonesia Through the High-Quality of Virtual Community and Knowledge Portal," in 6th European Conference on e-Government, Marburg, (2006)

5. E. Sofiah and Y. Septiana, "Sistem Pendukung Keputusan Feasibility Study untuk Menilai Kelayakan Sebuah Bisnis," Jurnal Wawasan Ilmiah, vol. 8, no. 1, pp. 1-7, (2017)

6. M. Siegrist and H. Gutscher, "Natural hazards and motivation for mitigation behavior: People cannot predict the affect evoked by a severe flood," Risk Analysis, vol. 28, no. 3, pp. 771-778, (2008)

7. Z. Zhou, S. Liu, G. Zhong and Y. Cai, "Flood disaster and flood control measurements in Shanghai," Natural Hazards Review, vol. 18, no. 1, p. B5016001, (2016)

8. P. Bubeck, W. J. Botzen and J. C. Aerts, "A review of risk perceptions and other factors that influence flood mitigation behavior," Risk analysis, vol. 32, no. 9, pp. 1481-1495, (2012)

9. Y. Septiana, D. Kurniadi and A. Mulyani, "Perancangan Program Aplikasi Faraidh sebagai Sistem Pendukung Keputusan Pembagian Harta Waris Berorientasi Solver," Jurnal Algoritma, vol. 14, no. 2, pp. 474-480, (2017)

10. C. Slamet, A. Rahman, A. Sutedi, W. Darmalaksana, M. A. Ramdhani and D. S. Maylawati, "Social

\footnotetext{
* Corresponding author: yseptiana@,sttgarut.ac.id
} 
Media-Based Identifier for Natural Disaster," IOP Conference Series: Materials Science and Engineering, vol. 288, no. 2017, p. 012039, (2018)

11. C. Slamet, R. Andrian, D. S. Maylawati, Suhendar, W. Darmalaksana and M. A. Ramdhani, "Web Scraping and Naïve Bayes Classification for Job Search Engine," IOP Conference Series: Materials Science and Engineering, vol. 288, no. 2017, p. 012038, (2018)

12. Y. A. Gerhana, W. B. Zulfikar, A. H. Ramdani and M. A. Ramdhani, "Implementation of Nearest Neighbor using HSV to Identify Skin Disease," IOP Conference Series: Materials Science and Engineering, vol. 288, no. 2017, p. 012153, (2018)

13. A. Rahman, C. Slamet, W. Darmalaksana, Y. A. Gerhana and M. A. Ramdhani, "Expert System for Deciding a Solution of Mechanical Failure in a Car using Case-based Reasoning," IOP Conference Series: Materials Science and Engineering, vol. 288, no. 2017, p. 012011, (2018)

14. C. Slamet, A. Rahman, M. A. Ramdhani and W. Darmalaksana, "Clustering the Verses of the Holy Qur'an using K-Means Algorithm," Asian Journal of Information Technology, vol. 15, no. 24, pp. 51595162, (2016)

15. W. B. Zulfikar, Jumadi, P. K. Prasetyo and M. A. Ramdhani, "Implementation of Mamdani Fuzzy Method in Employee Promotion System," IOP Conference Series: Materials Science and Engineering, vol. 288, no. 2017, p. 012147, (2018)

16. D. S. Maylawati, M. A. Ramdhani, A. Rahman and W. Darmalaksana, "Incremental technique with set of frequent word item sets for mining large Indonesian text data," in International Conference on Cyber and IT Service Management, Denpasar, (2017)

17. A. Taofik, N. Ismail, Y. A. Gerhana, K. Komarujaman and M. A. Ramdhani, "Design of Smart System to Detect Ripeness of Tomato and Chili with New Approach in Data Acquisition," IOP Conference Series: Materials Science and Engineering, vol. 288, no. 2017, p. 012018, (2018)

18. C. Giardino, N. Paternoster, M. Unterkalmsteiner, T. Gorschek and P. Abrahamsson, "Software development in startup companies: the greenfield startup model," IEEE Transactions on Software Engineering, vol. 42, no. 6, pp. 585-604, (2016)

19. N. M. A. Munassar and A. Govardhan, "A comparison between five models of software engineering," IJCSI, vol. 5, pp. 95-101, (2010)

20. D. Kurniadi, S. Sasmoko, H. L. H. S. Warnars and F. L. Gaol, "Software size measurement of student information terminal with use case point," in 2017 IEEE International Conference on Cybernetics and Computational Intelligence (CyberneticsCom), (2017)

21. R. G. Sabale and A. R. Dani, "Comparative study of prototype model for software engineering with system development Life Cycle," IOSR Journal of Engineering, vol. 2, no. 7, pp. 21-24, (2012)

22. D. M. Buede and M. W. D, The engineering design of systems: models and methods, John Wiley \& Sons, (2016)

23. H. M. Chen, R. Kazman and S. Haziyev, "Strategic prototyping for developing big data systems," IEEE Software, vol. 33, no. 2, pp. 36-43, (2016)

24. A. Saxena and P. Upadhyay, "Waterfall vs. prototype: Comparative study of sdlc," Imperial Journal of Interdisciplinary Research, vol. 2, no. 6, (2016)

25. M. Kaur and J. Pal, "Distance Measurement of Object by Ultrasonic Sensor HC-SR04,” Int'1 Journal for Scientific Research \& Development, vol. 3, no. 05, (2015)

26. Y. A. Tuwaidan, V. C. Poekoel and D. J. Mamahit, "Rancang Bangun Alat Ukur Desibel (dB) Meter Berbasis Mikrokontroler Arduino Uno R3," Ejournal Teknik Elektro dan Komputer, vol. 4, no. 1, pp. 37-43, (2015)

27. J. M. Alonso, A. J. Calleja, D. Gacio, J. Cardesín and E. López, "A long-life high-power-factor HPS-lamp LED retrofit converter based on the integrated buckboost buck topology," In IECon 2011-37th Annual, pp. 2860-2865, (2011)

28. W. C. Cheng, Y. Hou and M. Pedram, "Power minimization in a backlit TFT-LCD display by concurrent brightness and contrast scaling," In Proceedings of the conference on Design, automation and test in Europe, vol. 1, p. 10252, (2004)

29. M. A. Desima, P. Ramli, D. F. Ramdani and S. Rahman, "Alarm system to detect the location of IOT-based public vehicle accidents," In Computing, Engineering, and Design 2017 International Conference on. IEEE, pp. 1-5, (2017) 